\title{
Academic Libraries as user-centered organizations. Case study: Quality of services provided by LBUS Library
}

\author{
Elena Mărginean ${ }^{1}$, Claudiu Vasile Kifor ${ }^{2}$ \\ 1 "Lucian Blaga" University of Sibiu, The LBUS Library, 10 Victoriei Blvd., Sibiu, Romania \\ 2 "Lucian Blaga" University of Sibiu, Faculty of Engineering, 10 Victoriei Blvd., Sibiu, Romania
}

\begin{abstract}
Ever-growing digital services determine libraries to update almost all of their activities. Traditional library services must be transformed into electronic libraries, and library specialists must always be prepared for advanced digital services to come. Thus, libraries in the digital era must offer digital deposit services, digitisation services, research data management, metadata creation, digital cataloguing and conserving, and counselling in what regards digital copyrights, informational alphabetising. In this article, the emphasis falls on the necessity of developing and transforming libraries, bringing awareness to their role and their importance for society and at an individual level.
\end{abstract}

\section{Introduction and literature review}

In the UN agenda for 2030, the access to information has been the aim of the Goal 16 for sustainable development (Goal 16.10: Ensure public access to information and protect fundamental freedoms, in accordance with national legislation and international agreements). According to the Lyon Declaration in regard to accessing information an development, ,Half the world population does not have access to online information. In our society of knowledge, libraries offer access and opportunities for everyone" [1].

In 2016, IFLA (The International Federation of Library Associations and Institutions) launched an international programme for consolidation of ability, devised to promote and support the role of libraries in planning and implementing the UN agenda for 2030. At the same time, through the Declaration concerning libraries and development, it states [2]:

- Libraries give chances for everyone

- Libraries help people in their own development

- Libraries offer access to knowledges of the world

- Libraries offer expertise

- Libraries are part of the society

- Libraries need to be recognized as development politics.

Even though the role of libraries is not always well-established, they represent institutions of trust, which people already know as institutions offering quality information, adequately filtered and processed. Subsequently, as Einasto (2019) also claims, libraries have to be 
well organized ,as a disciplinary space, with proper etiquette and communication and behavior" [3].

In recent years, academic libraries, which are attached to a higher education institution, and serve to support the research curriculum of the faculty and students (Bates and Maack, 2010), have undergone various transformations. Their current concern is mainly focused on providing access to information and digital resources, virtual reference services and research services [4]. More and more authors, including Shoham and Klain-Gabbay (2019), concluded that the preferred model of academic library in the information age is the multidisciplinary library, which contains resources in a variety of fields and offers complete virtual services [5].

As Kim, J.A. (2016, p. 510) claims, in the integration of information technology in the library facilities has transformed it from a physical space focused on printed collections to a place for connection and collaboration, a more pleasant destination for discovery and learning [6]. Duran (2007, p.79) also mentions ,utilizing informational technology determines the shortening the time to complete activities, makes communication faster, increases ability to process" [7].

In 2016, Jain, P. \& Akakandelwa, A. researched academic libraries all over the world, they claimed that major and notable developments in academic libraries include scientific online communication, mobile technologies, the application of social mediation, digital preservation and preservation.In order to fit into this new informational landscape, academic librarians must take on new roles, develop new skills and competencies[8].

Furthermore, as stated by Jean, RJ, Kim, D., \& Cavusgil, E. (2020, p. 55), we must be extremely aware that digitalization not only brings opportunities, it also creates new types of threats and risks [9]. Especially since digitization means more than the use of digital content. Skills are needed for library staff and users, in order to be operational in this environment.

It is very clear that over time libraries will face a large increase in electronic resources, and this increase may lead to extending the capacity of existing library systems. Big data requires a shift in library management thinking, from resource management to data management ( $\mathrm{Li}$ et al. 2019) [10]. In addition to the amount of electronic data, it has become very important to preserve them, so they can be consulted over the years without losing parts of the original creation.

\section{Creation and protection of value in the Academic Library}

Academic libraries do not function independently, they are organized as support structures in addition to the universities to which they belong. As a result, their development strategy and vision must be aligned and closely linked to that of the coordinating institution.

Horava (2014) stated that before universities, academic libraries must convincingly demonstrate their value, or risk being diminished or replaced. In today's world of new forms and sources of knowledge, as new tools for data manipulation rapidly change user behaviors and expectations, perceptions of library activity based on library collections, spaces and services are very important [11].

In this sense, the evaluation process carried out at the level of an academic library has become very important. This, as stated by Lewin and Passonneau (2012, p. 90) helps the library demonstrate its place in the field of higher education. At the same time, it helps establish the direction and methodology for improving their services and resources and to understand the value and impact of libraries on the process of research, teaching and 
learning. Furthermore, it brings information about the challenges and successes of current services and resources [12].

The academic library creates value through its very mission. When analyzing the value in the academic library, the value incorporated in the products and services offered is very important, in addition to the value of the library itself conferred by the resources held (assets: land, building, documents, etc.). It is not the quantity that matters, the number of resources or services offered, but the nature of those resources, services, activities or programs offered. These will be sent to users at the time of the exchange.

Kim (2011, p. 118) emphasized that, from the beneficiary's point of view, academic libraries provide value for the university, as a subordinate institution, for its users and for itself, as an organization [13]. The value for users is paramount, the other two being derivatives of it. In this case, it is important to know if the users get enough value to spend their physical or virtual time in the library, if the amount spent by / for the library is justified, if they need something other than what is offered to them. Do there have to be more valuable things for the library to do for users and for the coordinating institution, in order to justify their existence, costs, development?

Academic libraries develop value-added services, thus exploiting their role as specialist intermediaries for the organization and retrieval of information resources. At the same time, they can also add value to the research process. Two centuries ago, Karl Marx stated: "The source of surplus value is labor." In the case of an academic library, the value of the workforce, represented by the library staff, through the skills they have and which they demonstrate will incorporate value on the newly created good / service. At the time of the exchange, this value will add value to the user, contributing to the creation and development of new workforce in all areas of activity, the creation of intellectual capital, the creation of knowledge, generators of innovation. As a result, the value created contributes to value creation in the future, the resulting intellectual product becoming the raw material to produce goods and services in the future.

There are many authors who argue that, in terms of value, there is a correlation between library use and academic success. Todorinova (2018, p. 209) stated that libraries should support students' development, thus improving their analysis and synthesis of information into ideas, in writing [14]. However, the idea that there is a link between not using the library and dropping out of university is also worth checking.

Demonstration of the full value of the academic library can only be achieved when there is sufficient evidence of the impact of the library on its users.

\section{Towards the digimodern library}

The digimodern library is a user-led library. Users are not library experts, they are experts in being users, therefore the information obtained from them is extremely valuable to the library. As a result, one needs to research and understand the demands and expectations of users, as they can contribute to the organization of library space and services directly and at a lower cost, rather than using other tools and methods (Einasto, 2019, p.165) [3]. 
Figure 1. Digimodern Library Model

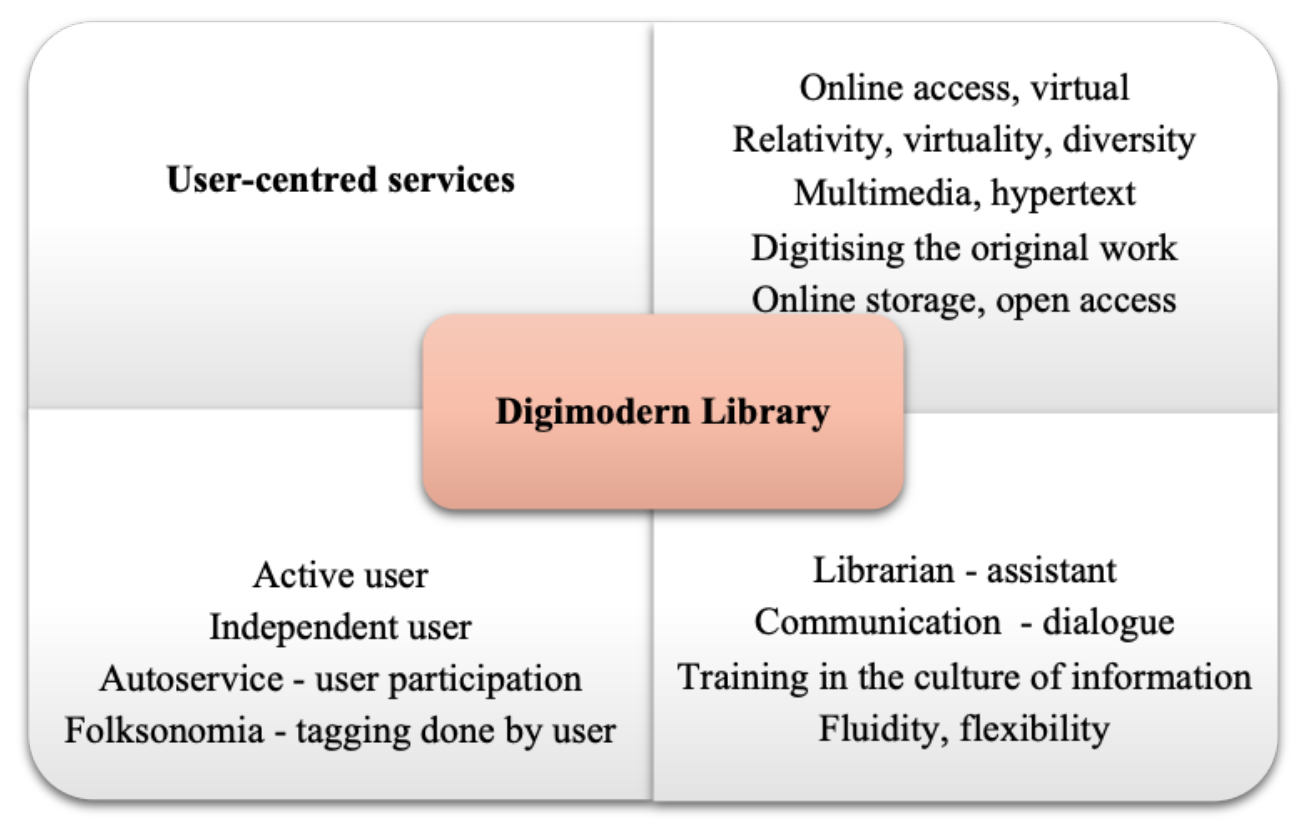

Source: Own synthesis based on information from the work of the author Einasto (2019, p. 165) [3]

In fact, the modern library is seen as integrated into the "Library 2.0" model, a usercentered library, where change is encouraged, with users being invited to participate in creating the physical and virtual services they want (Stejskal and Hajek 2015) [15].

Current digital transformations ahave given rise to active users who, have created communities of common interest with the use of social media, either to evaluate documentary resources, or to share online search experiences, or to exchange impressions, wishes, recommendations.

The user's involvement in the self-service process, as a new strategy for communicating collections in the digimodern library, will lead to an increase in access to its digital collections, especially as the labeling trend, through the vocabulary controlled by the librarian, disappears. Thus, what in the literature is called "folksonomy", "A user-generated system of classifying and organizing online content into different categories by the use of metadata such as electronic tags.", by using metadata such as electronic tags easy to understand and do, even without previous training and knowledge in classification or indexing [16].

In terms of human resources in academic libraries, more and more authors consider it important to develop new roles for librarians. Thus Jain and Akakendelwa (2016, p.147) call them managers and knowledge workers, training partners in learning spaces, data managers and curators, research supporters, content producers and disseminators, curriculum developers, experts in the use of and training in new technologies [8].

These new roles require improving the level of skills and abilities of staff, librarians need to acquire multiple skills: in research, communication, data management and dissemination, in 
digital literacy. Availability and promptness are characteristics that librarians must demonstrate and in the future, users will continue to need the services they provide.

As a result, libraries must continually reinvent their relationship with their users. They must take on these new roles that involve changes in the services provided, staff, available space and access to collections. The new structure highlights the importance of services offered to users. This also has an influence on the organization of collections. The library activities management has as main objective the increase of the performance indices of the managed system. Properly structured information provided on time and on adequate support, is the result of the work in this sector, therefore the performance indices can be associated with the level of satisfaction of these requirements.

\section{Case study: The quality of services offered by the LBUS Library}

The case study starts from the premise that the LBUS (Lucian Blaga University of Sibiu) Library, like any other efficient service organization, tries to meet all possible requests of its beneficiaries, both in depth and as an extension, by maximizing the capacity of the service, without affecting the level of its quality. This hypothesis is suggestively represented in the figure below:

Figure 2. The academic library-user relationship

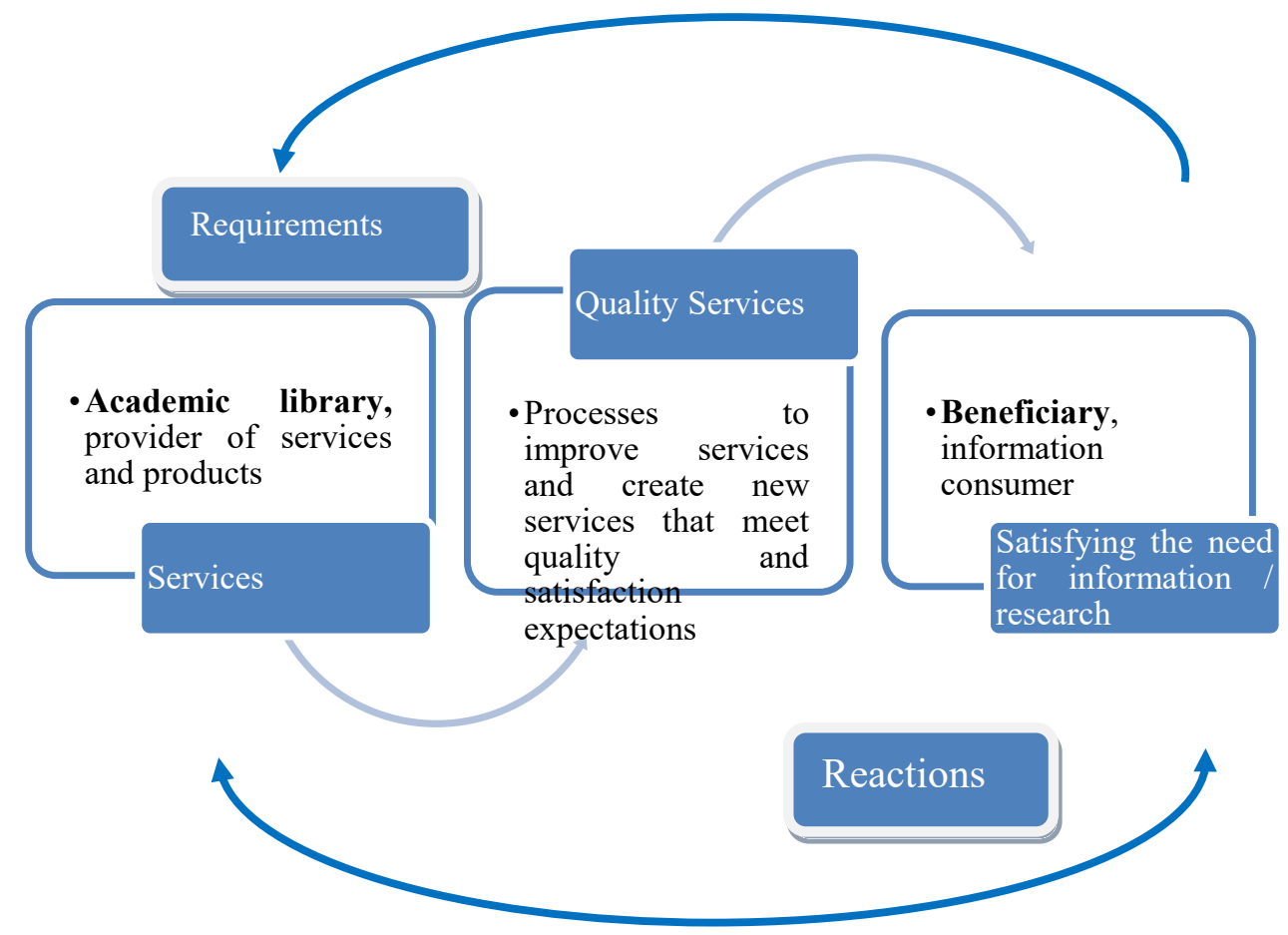


Thus, within the Library of the "Lucian Blaga" University of Sibiu, using the method of empirical research - survey based on a questionnaire - we undertook research on the topic "Improving the activity of the library and increasing the quality of services provided".

The main objective was the analysis of the satisfaction of the library users, and of their expectations in order to support the research activity and to meet the need for information documentation. In order to achieve this objective, we start from the hypothesis according to which the better you know the offers and the types of services provided, the better you can manage them and you will orient them more towards the users' needs.

We applied questionnaires among library users, the sample consisting of 102 subjects, thus seeking to determine the complexity and usefulness of existing info-documentary sources and the degree of satisfaction of LBUS Library users. The questions tackled: the ease of finding a book on the shelf, the ease of finding a periodical publication on the shelf, the ease of finding another type of document, the documentary area of existing publications, access to a publication that did not exist in the library, the ease of browsing the library's website, which facilitates finding information in the library's online catalog. All these aspects have been pursued on varying degrees of importance, ranging from very important to important, accessible, somewhat important, totally unimportant, I do not use it.

As a result of the data processing, we found that the most important aspects from the point of view of LBUS Library users are related to accessibility, to the library's ability to provide access to its collections in any format.

Figures 3: Finding the information in the electronic catalog of the library

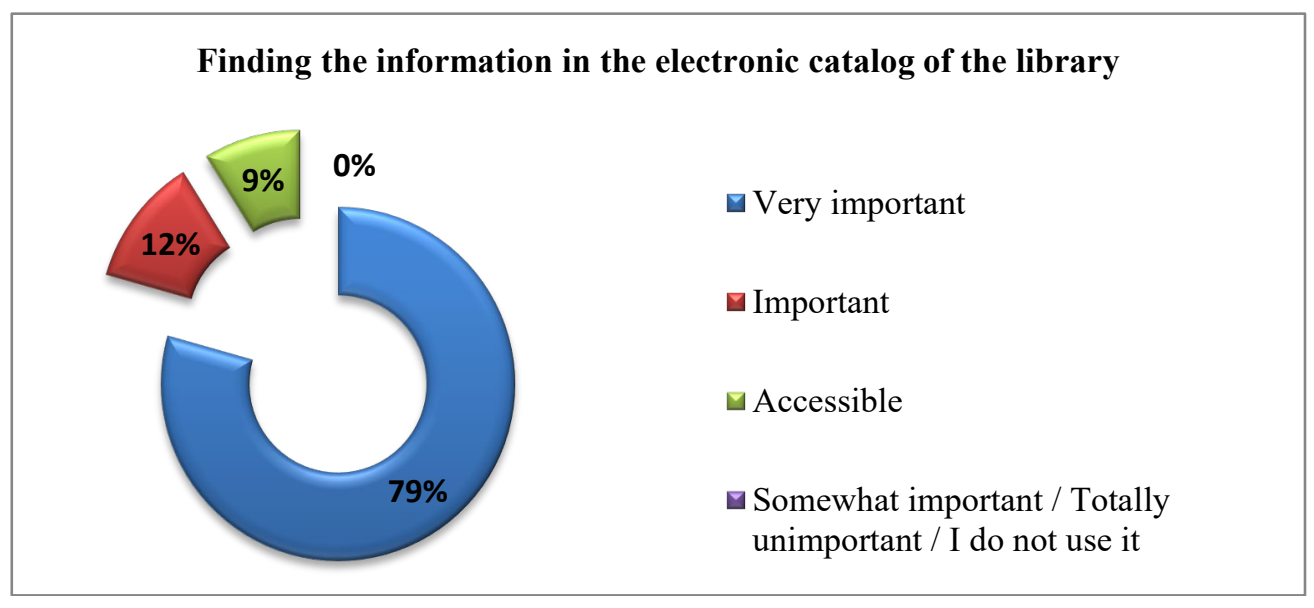

Furthermore, we considered it it was important to make a correlation between the degree of satisfaction with the importance granted to the ease of browsing the library website?

Because the library website is the starting point for obtaining any information. From here, users have access to the online catalog, to bibliographic and bibliometric databases, to any news related to information - documentation - research. Also here are the contact details and information they can get "by asking a librarian". 
Table 1: Level of importance as assigned by LBUS user - ease of browsing the library website

\begin{tabular}{|l|l|l|}
\hline & answers & percent \\
\hline Very important & 75 & 73 \\
\hline Important & 9 & 9 \\
\hline Accessible & 15 & 15 \\
\hline Somewhat important & 0 & 0 \\
\hline Totally unimportant & 3 & 3 \\
\hline I do not use it & 0 & 0 \\
\hline
\end{tabular}

Table 2: Satisfaction towards library services - ease of browsing the library website

\begin{tabular}{|l|l|l|}
\hline & answers & percent \\
\hline Highly satisfied & 54 & 52 \\
\hline Satisfied & 18 & 18 \\
\hline Acceptable level of satisfaction & 15 & 15 \\
\hline Low level of satisfaction & 15 & 15 \\
\hline Not at all satisfied & 0 & 0 \\
\hline I do not use it & 0 & 0 \\
\hline
\end{tabular}

Table 3: Correlations between the level of satisfaction and the importance - ease of browsing the library website

\begin{tabular}{|c|c|c|c|c|c|c|c|}
\hline \multirow[b]{2}{*}{ I } & \multicolumn{7}{|c|}{ LEVEL OF SATISFACTION } \\
\hline & $\sum$ & 54 & 18 & 15 & 15 & 0 & 0 \\
\hline $\begin{array}{l}\text { M1 } \\
P\end{array}$ & 75 & 52 & 2 & 10 & 11 & 0 & 0 \\
\hline $\mathrm{O}$ & 9 & 1 & 8 & 0 & 0 & 0 & 0 \\
\hline $\mathrm{T}$ & 15 & 1 & 7 & 3 & 4 & 0 & 0 \\
\hline A & 0 & 0 & 0 & 0 & 0 & 0 & 0 \\
\hline $\mathrm{C}$ & 3 & 0 & 1 & 2 & 0 & 0 & 0 \\
\hline $\mathrm{E}$ & 0 & 0 & 0 & 0 & 0 & 0 & 0 \\
\hline
\end{tabular}

It is noteworthy that, out of the 75 users ( $74 \%$ of the total respondents) who consider it very important to easily find information on the library's website, only 52 (respectively $69 \%$ of those who believe this is highly important) are very satisfied, while 2 (respectively $3 \%$ ) are satisfied, and for 10 of them $(13 \%)$ it is acceptable and $11(15 \%)$ are low level of satisfaction

Analysing these correlations, we notice that, in general, users are satisfied with the ease of finding the resources they need in the library, and less satisfied by the way in which the library website meets their information needs. 
Figures 4: Finding the information on the library webpage

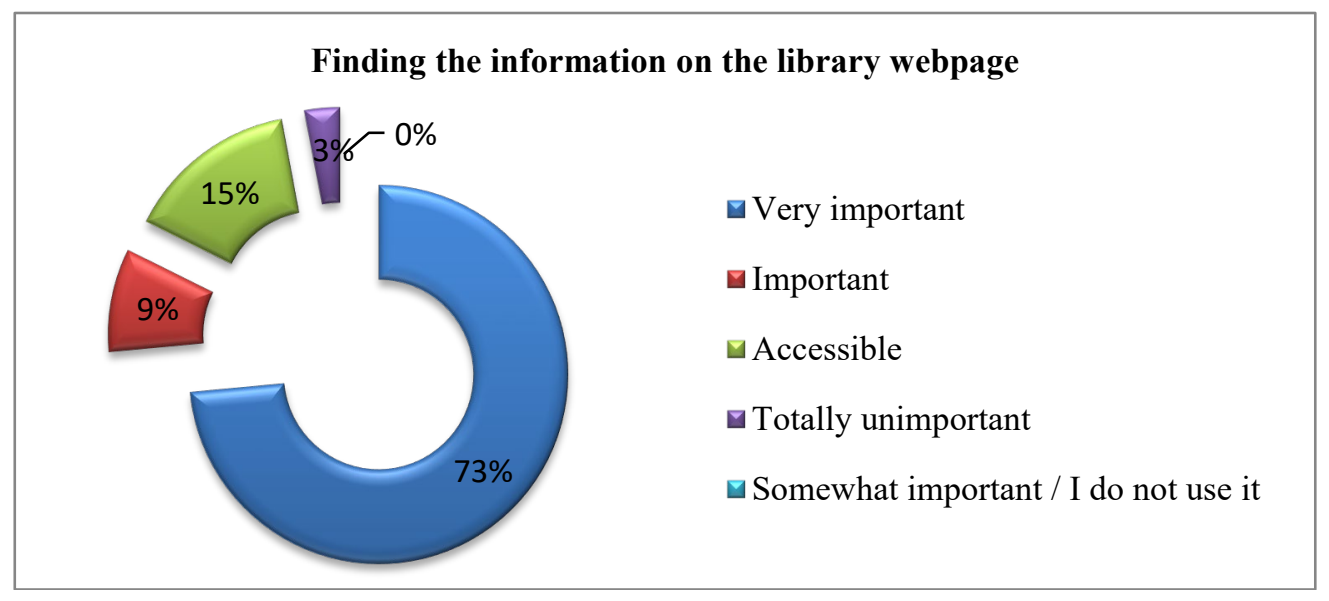

Figures 5: Documentary Area

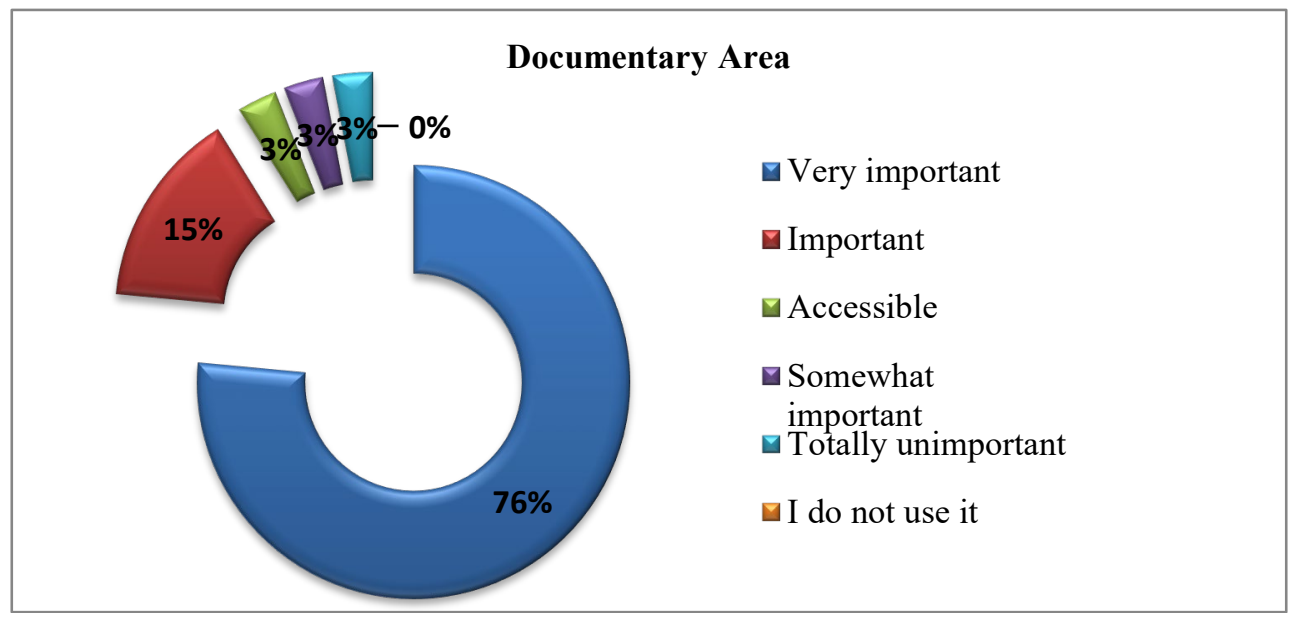

Therefore, we can conclude that it is very important that high quality library services meet the expectations of users. It is important for them to appear as a result of identifying their needs, to ensure their satisfaction, to implement library criteria and principles of professional ethics, to bring efficiency and economic efficiency.

\section{Conclusions}

By analyzing all the aspects above, we can say that, for libraries, the problems of today and the challenges of the future are related to human resources, funding and institutional management. It is very important that libraries keep up with what is new in their field of activity. Furthermore, it is important for them to align their services with what is happening 
in economically developed countries, to dose their efforts to meet the requirements of their users.

As a result, academic libraries need to evolve, to change constantly, mainly due to everchanging information technologies, to improve the level of skills and abilities of staff, to find new ways to attract users, to increase the quality of services offered, to brings satisfaction.

The academic library, through a management based on strategic growth and development, must permanently increase the quality of the services offered to attract more users and to increase its value, a value that appears only when its resources are used.

\section{References}

1. Lyon Declaration on Access to Information and Development. Available on https://www.lyondeclaration.org/

2. IFLA Statement on Libraries and Development. Available on https://www.ifla.org/node/7982

3. O. Einasto, Library Communication in the Era of Digimodernism, Qualitative and Quantitative Methods in Libraries (QQML), Vol 8(No 2 (2019): June 2019), 159-168 (2019)

4. M.J. Bates, M.N. Maack, Encyclopedia of library and information sciences. Boca Raton, FL: CRC Press (2010)

5. S. Shoham, L. Klain-Gabbay, The academic library: Structure, space, physical and virtual use, Journal of Academic Librarianship, 45(5) (2019)

6. J.A. Kim, Dimensions of User Perception of Academic Library as Place, Journal of Academic Librarianship, 42(5), 509-514 (2016)

7. C.D. Duran, Aspecte privind evaluarea riscului ca sursă a deciziei la nivelul firmei : Teză de doctorat. Timişoara: Editura Politehnica (2007)

8. Jain, P., \& Akakandelwa, A., Challenges of twenty-first century academic libraries in Africa, African Journal of Library Archives and Information Science, 26(2), 147-155 (2016)

9. R.J. Jean, D. Kim, E. Cavusgil, Antecedents and outcomes of digital platform risk for international new ventures' internationalization, Journal of World Business, 55(1) (2020)

10. S. Li, F. Jiao, Y. Zhang, X. Xu, Problems and Changes in Digital Libraries in the Age of Big Data From the Perspective of User Services, Journal of Academic Librarianship, 45(1), 22-30 (2019)

11. T. Horava, Risk Taking in academic libraries: The implications of prospect theory, Library Leadership and Management, 28(2) (2014)

12. H.S. Lewin, S.M. Passonneau, S. M., An Analysis of Academic Research Libraries Assessment Data: A Look at Professional Models and Benchmarking Data, Journal of Academic Librarianship, 38(2), 85-93 (2012)

13. G. Kim, A critical review of valuation studies to identify frameworks in library services, Library and Information Science Research, 33(2), 112-119 (2011)

14. L. Todorinova, A Mixed-Method Study of Undergraduate and First Year Librarian Positions in Academic Libraries in the United States, Journal of Academic Librarianship, 44(2), 207-215 (2018)

15. J. Stejskal, P. Hajek, Effectiveness of digital library services as a basis for decision-making in public organizations, Library and Information Science Research, 37(4), 346-352 (2015)

16. Meaning of folksonomy. Available on https://www.lexico.com/en/definition/folksonomy 